\title{
A Trojan horse saddle stuck in the lung
}

\author{
Lovely Chhabra, Vinod K Chaubey
}

Saint Vincent Hospital, University of Massachusetts Medical School, Worcester Massachusetts, USA

\section{Correspondence to} Dr Lovely Chhabra, lovids@hotmail.com

\section{(1) crossanak}

To cite: Chhabra $\mathrm{L}$, Chaubey VK. BMJ Case Rep Published online: [please include Day Month Year] doi:10.1136/bcr-2013203081

\section{DESCRIPTION}

A 61-year-old man with a history of hypertension and obesity presented with acute onset dyspnoea, light-headedness and right-sided pleuritic chest pain. The physical examination showed sinus tachycardia and a right-sided pleural rub. Oxygen saturation on initial presentation was $89 \%$ on room air by pulse oximetry. A 12-lead ECG showed a new S1Q3T3 pattern (figure 1A). Contrast-enhanced chest CT showed a large saddle pulmonary embolism (PE), with extensive involvement of several segmental and subsegmental arteries (figure 1B), a wedge-shaped opacity in the right middle lobe suggesting a pulmonary infarct and a small right pleural effusion (figure 1C,D). Bedside echocardiography did not indicate any right ventricular strain. The patient was started on a heparin drip. Bilateral lower extremity venous duplex revealed extensive bilateral deep vein thrombosis and a retrievable inferior vena cava filter was placed. The patient improved clinically and was discharged on warfarin.

\section{DISCUSSION}

An ECG may show signs of right heart strain or acute cor pulmonale in cases of large PEs; the classic signs are a large $\mathrm{S}$ wave in lead $\mathrm{I}$, a large $\mathrm{Q}$ wave in lead III and an inverted Twave in lead III (S1Q3T3 sign), which occurs in $12-50 \%$ of people with the diagnosis but may occur in $12 \%$ without the diagnosis. ${ }^{12}$ The most common ECG signs in PE reported by different series, however, are non-specific ST-T changes. ${ }^{1}$ Other commonly reported ECG changes in PE are sinus tachycardia (8-69\% of cases) and incomplete or complete right bundle branch block $(6-67 \%) .{ }^{1-3}$ Axis changes are also common. While right axis deviation has often been described as the 'classic' axis deviation, left axis deviation is also equally common. In fact, left axis deviation has been reported to occur more frequently in patients with pre-existing cardiopulmonary disease. ${ }^{1-5}$ The gold standard for diagnosing PE is pulmonary angiography. However, CT pulmonary angiography (CTPA) is a non-invasive modality which is obtained using CT with radiocontrast rather than right heart catheterisation. It is considered clinically equivalent to angiography for the diagnosis of PE. CTPA is the recommended first-line diagnostic imaging test in most people, except in those with renal dysfunction where its use is limited.

\section{Learning points}

An ECG may show the classic S1Q3T3 sign in a large pulmonary embolism (PE) (a large $S$ wave in lead $\mathrm{I}$, a large $\mathrm{Q}$ wave in lead III and an inverted T wave in lead III). It may occur in $12-50 \%$ of people with the confirmed diagnosis but may occur in $12 \%$ without the diagnosis.

- The most commonly seen ECG signs in pulmonary embolism are non-specific ST-T changes, sinus tachycardia and right bundle branch block.

- The gold standard for diagnosing PE is pulmonary angiography. However, CT pulmonary angiography is a non-invasive modality which is clinically equivalent to angiography for the diagnosis of PE.

Contributors Both authors contributed significantly to the manuscript and have seen and approved the manuscript prior to submission.

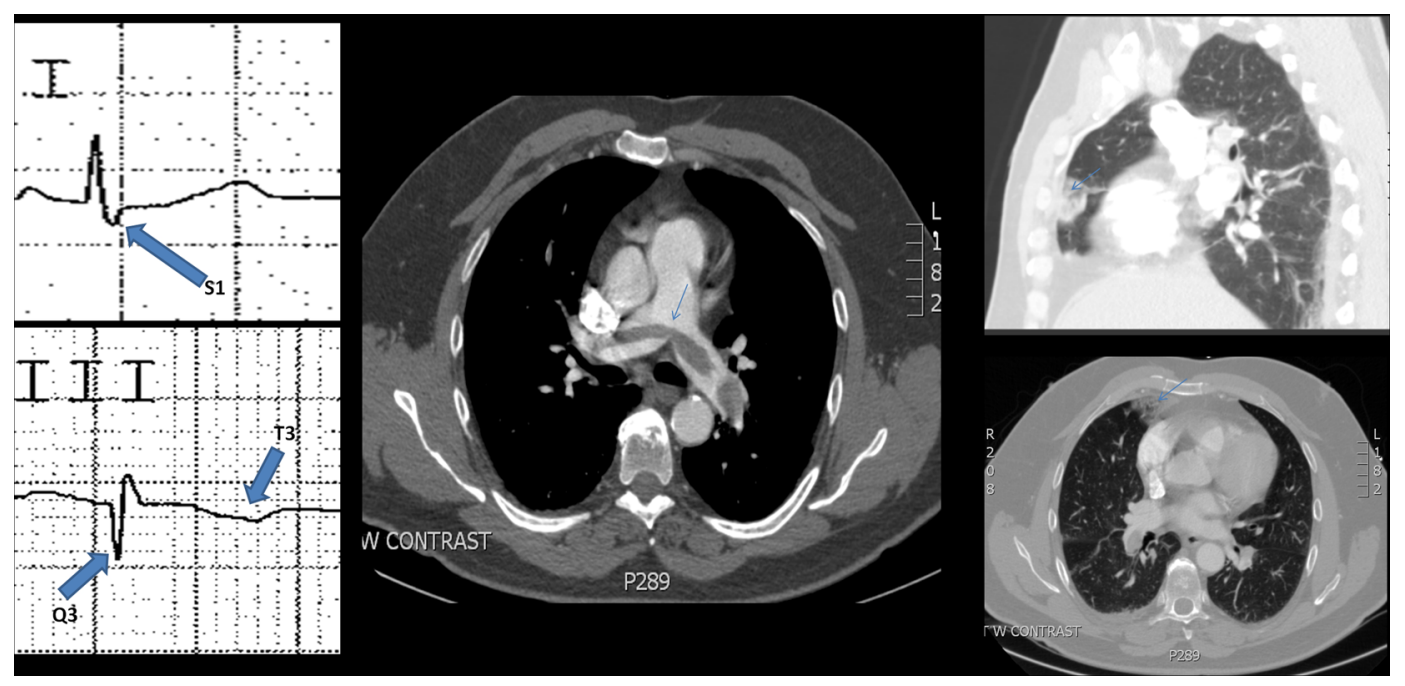

Figure 1 (A) A 12-lead ECG showing a new S1Q3T3 pattern. (B-D) Contrast-enhanced chest CT showing a large saddle pulmonary embolism with extensive involvement of several segmental and subsegmental arteries (B), a wedge-shaped opacity in the right middle lobe suggesting a pulmonary infarct and a small right pleural effusion $(C, D)$. 
Competing interests None.

Patient consent Obtained.

Provenance and peer review Not commissioned; externally peer reviewed.

\section{REFERENCES}

1 Todd K, Simpson CS, Redfearn DP, et al. ECG for the diagnosis of pulmonary embolism when conventional imaging cannot be utilized: a case report and review of the literature. Indian Pacing Electrophysiol J 2009;9:268-75.
2 Chan CT, Vilke GM, Pollack M, et al. Electrocardiographic manifestations: pulmonary embolism. J Emerg Med 2001;21:

$263-70$.

3 Ullman E, Brady WJ, Perron AD, et al. Electrocardiographic manifestations of pulmonary embolism. Am J Emerg Med 2001;19:514-19.

4 Stein PD, Dalen JE, McIntyre KM, et al. The electrocardiogram in acute pulmonary embolism. Prog Cardiovasc Dis 1975;17:247-57.

5 Spodick DH. Electrocardiographic responses to pulmonary embolism. Mechanisms and sources of variability. Am J Cardiol 1972;30:695-9.

Copyright 2014 BMJ Publishing Group. All rights reserved. For permission to reuse any of this content visit http://group.bmj.com/group/rights-licensing/permissions.

BMJ Case Report Fellows may re-use this article for personal use and teaching without any further permission.

Become a Fellow of BMJ Case Reports today and you can:

- Submit as many cases as you like

- Enjoy fast sympathetic peer review and rapid publication of accepted articles

- Access all the published articles

- Re-use any of the published material for personal use and teaching without further permission

For information on Institutional Fellowships contact consortiasales@bmjgroup.com

Visit casereports.bmj.com for more articles like this and to become a Fellow 